\title{
Sugarcane spatial-temporal monitoring and crop coefficient estimation through NDVI
}

\author{
Angelo B. Alface ${ }^{1}$, Silvio B. Pereira ${ }^{2}$, Roberto Filgueiras ${ }^{2} \&$ Fernando F. Cunha $^{2}$ \\ ${ }^{1}$ Universidade Zambeze/Faculdade de Engenharia Agronômica e Florestal. Cidade de Mocuba, Província de Zambézia, Moçambique. E-mail: \\ angeloalface@gmail.com - ORCID: 0000-0003-4667-2681 \\ ${ }^{2}$ Universidade Federal de Viçosa/Departamento de Engenharia Agrícola. Viçosa, Minas Gerais, Brasil. E-mail: silviopereira@ufv.br - ORCID: 0000- \\ 0001-8491-144X; roberto.f.filgueiras@ufv.br (Corresponding author) - ORCID: 0000-0002-0186-8907; fernando.cunha@ufv.br - ORCID: 0000- \\ 0002-1671-1021
}

\begin{abstract}
The use of satellite images as a complement in irrigation management constitutes a primordial basis in the decision-making process for irrigated agriculture. In this context, the present study aimed to monitor through Normalized Difference Vegetation Index (NDVI) an irrigated sugarcane field belonging to the Mafambisse company, located at the District of Nhamatanda/Sofala, Republic of Mozambique, and establish its relationship with the crop coefficient established by FAO $\left(\mathrm{kc}_{\mathrm{FAO}}\right)$ and fit a regression model to estimate crop coefficient $(\mathrm{kc})$ from the relationship between NDVI and $\mathrm{kc}_{\mathrm{FAO}}$. The study was conducted using a series of Sentinel-2A/MSI images, relative to the period from October 2016 to October 2017. Based on the NDVI images generated, it was possible to monitor the sugarcane crop in the field and analyse the sensitivity of the index to its vegetative vigor. A similar pattern was observed between $\mathrm{kc}_{\mathrm{FAO}}$ profiles and NDVI values, which allowed the adjustment to be performed, demonstrating that this index is an alternative to obtain the crop coefficient.
\end{abstract}

Key words: irrigated agriculture, geotechnology, GIS

\section{Monitoramento espaço-temporal da cana-de-açúcar e estimativa do coeficiente de cultivo por meio do NDVI}

RESUMO: O uso de imagens de satélites como complemento na gestão de irrigação constitui uma base primordial no processo de tomada de decisão para a agricultura irrigada. Nesse contexto, o objetivo do trabalho foi monitorar, por meio do Índice de Vegetação por Diferença Normalizada (IVDN), a cultura da cana-de-açúcar irrigada pertencente à empresa Mafambisse, localizada no Distrito de Nhamatanda/Sofala, República de Moçambique; e estabelecer sua relação com o coeficiente da cultura estabelecido pela FAO $\left(\mathrm{kc}_{\mathrm{FAO}}\right)$ e ajustar um modelo de regressão para estimar o coeficiente de cultivo $(\mathrm{kc})$ a partir da relação entre IVDN e kc $\mathrm{FAO}_{\mathrm{FAO}}$. Para a condução da pesquisa foi utilizada uma série de imagens Sentinel-2A/MSI, referente ao período de outubro de 2016 a outubro de 2017. Por meio das imagens geradas de NDVI foi possível fazer o acompanhamento da cana-de açúcar em campo e analisar a sensibilidade do índice no vigor vegetativo da cultura. Observou-se padrão semelhante entre os perfis de $\mathrm{kc}_{\mathrm{FAO}}$ e os valores do NDVI, tornando possível a realização do ajuste, demostrando que esse índice é uma alternativa para obtenção do coeficiente de cultivo.

Palavras-chave: agricultura irrigada, geotecnologia, SIG 


\section{INTRODUCTION}

Monitoring crops in the field based on remote sensing, through satellite images, to calculate vegetation indices currently constitutes a gain for irrigated agriculture (Li et al., 2013; Gao et al., 2017), because it is viewed as a complementary resource of irrigation management (Alves et al., 2014; Agrosmart, 2017).

Among the vegetation indices developed, the Normalized Difference Vegetation Index (NDVI) is the most used, due to its sensitivity to the presence of pigments that participate in photosynthetic processes (Formaggio \& Sanches, 2017), as well as its easy application, allowing rapid and efficient detection of variations in the vegetation (Bernardi et al., 2014). This fact occurs because the spectral signature of the green, healthy vegetation shows evident contrast between the visible and near infrared regions, which are used by the NDVI (Shimabukuro et al., 1998).

Risso et al. (2012), analysing the application of NDVI with other indices in the soybean crop, concluded that NDVI had the best performance. Ribeiro et al. (2017) also concluded that NDVI was efficient in differentiating the distinct periods of cultivation in the corn crop.

An important application, among others, in the analysis with NDVI is related to the estimation of crop coefficient $(\mathrm{kc})$. As the attribution of $\mathrm{kc}$ values is directly related to crop phenological cycle, some studies have suggested that temporal profiles of NDVI can be used to obtained kc values (Singh \& Irmak, 2009; Kamble et al., 2013; Cattani et al., 2017).

Thus, the present study aimed to perform a spatial-temporal monitoring of sugarcane based on NDVI images, under center pivot, considering the irrigated perimeter of the Mafambisse company, located in Mozambique, and adjust a regression model to estimate crop coefficient $(\mathrm{kc})$ from the relationship between NDVI and $\mathrm{kc}_{\mathrm{FAO}}$

\section{Material ANd Methods}

The study was conducted using data obtained in the Republic of Mozambique, a country located in Southeastern Africa (Figure 1A), georeferenced between the parallels $10^{\circ} 27^{\prime}$ and $26^{\circ} 52^{\prime} S$ latitude and between the meridians $30^{\circ} 12^{\prime}$ and $40^{\circ} 51^{\prime}$ E longitude, datum WGS84, sexagesimal geographic coordinates (Figure 1B). It has 11 provinces, with coast extension of 2,500 km, occupying an area of 799,380 $\mathrm{km}^{2}$.

The Mafambisse sugar company, located in the district of Nhamatanda/Sofala, has 2,626 ha of sugarcane irrigated by 41 center pivots (Figure 1C). The district is located between the coordinates $19^{\circ} 36^{\prime} 57^{\prime \prime} \mathrm{S}$ and $34^{\circ} 44^{\prime} 19^{\prime \prime} \mathrm{E}$, datum WGS 84, sexagesimal geographic coordinates, at mean altitude of $44 \mathrm{~m}$ above the sea level. The District of Nhamatanda is partially inserted in the Pungwe River Basin, in the Beira corridor, a place used to catch water for irrigation.

The mean annual rainfall of the district varies from 1,000 to $1,460 \mathrm{~mm}$, with mean annual temperature of $27^{\circ} \mathrm{C}$, and minimum and maximum temperatures of 14 and $33^{\circ} \mathrm{C}$ are observed in July and January/February, respectively. According to Köppen's climatic classification, the climate of the district is encompassed by the zone of transition from rainy tropical to steppe climate, with dry season in the winter (MAE, 2005).

The areas irrigated by center pivots of the Mafambisse company have clay sandy soils. The sugarcane cultivars used in the area are: N14, N21, N25, N27 and N32, and N14 is the most used.

The center pivots of the study area were monitored by the Sentinel-2A satellite. Free images were obtained at the Earth Explorer website belonging to the United States Geological Survey (USGS). The necessary information was generated using the bands 4 and 8 , which corresponded to red and near infrared, respectively. The images used in the monitoring are

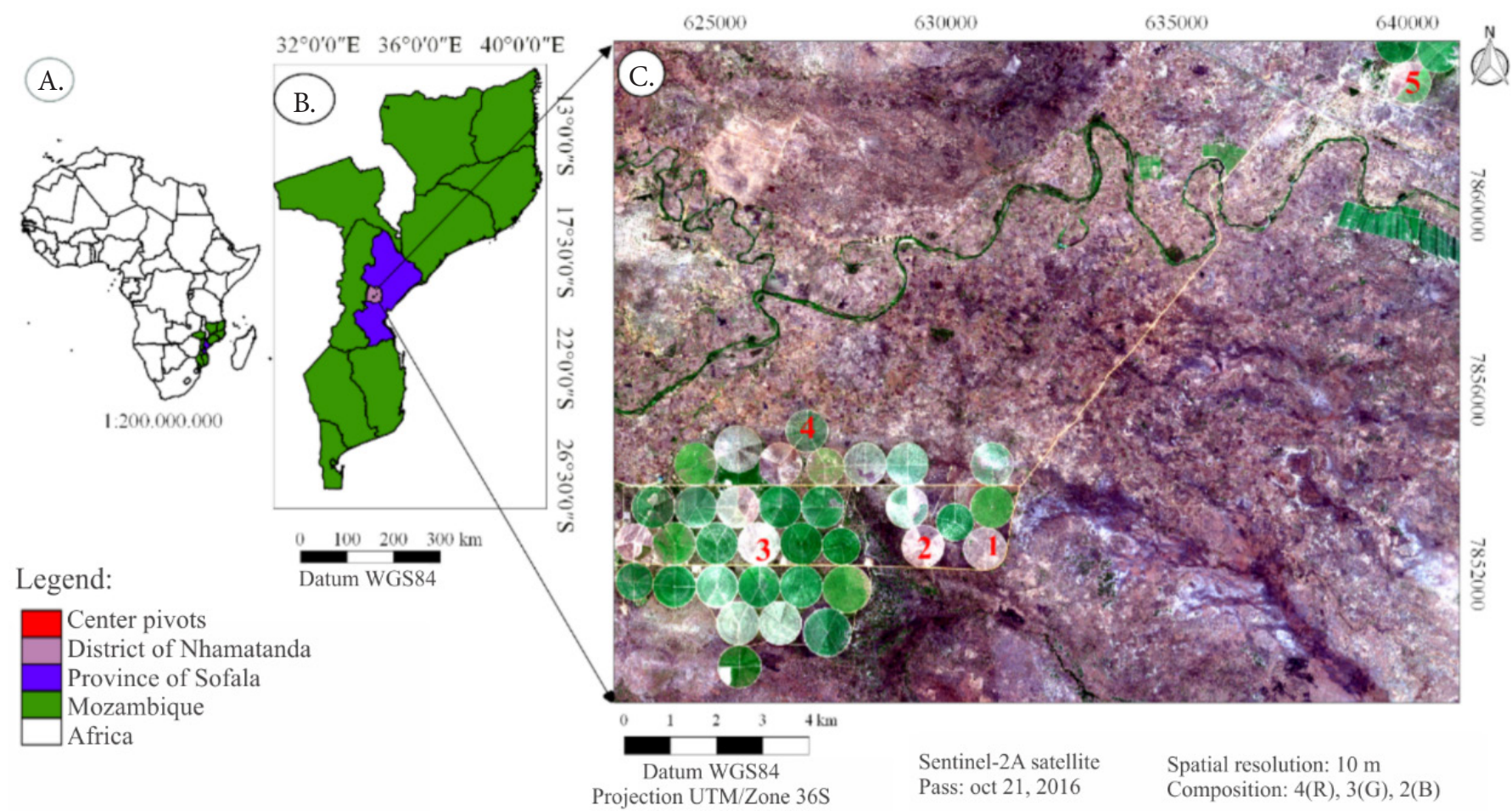

Figure 1. Geographic location of the study area: African continent (A), Republic of Mozambique (B) and center pivots of the Mafambisse company - District of Nhamatanda/Sofala (C) 
of the following dates: $21 / 10 / 2016,10 / 11 / 2016,10 / 12 / 2016$, 29/01/2017, 09/04/2017, 08/06/2017, 17/08/2017, 26/09/2017, $16 / 10 / 2017$ and $26 / 10 / 2017$.

After acquiring the images and in order to minimize the atmospheric effect on the reflectance data captured by the sensor, atmospheric correction was carried out by the Dark Object Subtraction (DOS-1) method using the Semi-Automatic Classification Plugin (SCP), available in QGIS 2.16.3 software (Congedo, 2016).

Images with clouds were disregarded, except the image of center pivot 4, date $29 / 01 / 2017$, which was kept in order to have a standard of dates with selected images of the center pivots, but the values corresponding to the clouds were extracted from the statistical analyses. The selected and analysed images encompassed different phases of the sugarcane phenological cycle.

In order to monitor the crop in the field, NDVI was calculated from the acquired images. The program QGIS 2.16.3 (QGIS Development Team, 2016) was used as a computational tool.

Areas of five center pivots of the Mafambisse sugar company, represented in Figure 1C, were selected for NDVI calculation using Eq. 1 (Moreira, 2011).

$$
\mathrm{NDVI}=\frac{(\mathrm{NIR}-\mathrm{R})}{(\mathrm{NIR}+\mathrm{R})}
$$

where:

NDVI - Normalized Difference Vegetation Index;

NIR - reflectance of near infrared band (band 8); and,

$\mathrm{R}$ - reflectance of red band (band 4 ).

NDVI values range from -1 to 1 , and areas occupied by denser vegetation tend to present NDVI close to 1 (higher vegetative vigor). Areas composed of water bodies or with presence of clouds have higher capacity of absorption in both bands, but the reflectance in the red band is higher than that in the near infrared band, which causes the values to be negative (Ponzoni et al., 2012; Cordeiro et al., 2017).

In exposed soil or less dense vegetation, positive values close to zero are obtained because under this condition there is higher absorption of radiation in the near infrared band, which explains the low values of NDVI (Lima et al., 2013).

Pixels with lower values, 0 to 0.05 range, received red color, representing exposed soil; pixels with variation from 0.05 to 0.26 received a salmon color (pinkish orange), representing a recently planted area, so that it is similar to the spectral behavior of exposed soil (Formaggio \& Sanches, 2017), or even areas with some process of degradation (Rodrigues \& Rodrigues, 2012); beige shade (close to white) was attributed to the range from 0.26 to 0.47 , representing areas with little biomass; the set of pixels in the range from 0.47 to 0.69 received a light green color, representing areas with green but still scarce vegetation, which may be related to vulnerable health of the crop (not healthy or under any water deficit) or even to the process of maturation; and the set of pixels with highest values, from 0.69 to 0.90 , received a dark green color, representing higher vegetative vigor of the crop.
From the values of crop coefficient (kc) obtained by the FAO56 bulletin, referred to here as $\mathrm{kc}_{\mathrm{FAO}}$, and the average values of NDVI, estimated for the sugarcane crop considering the data of pivot 2, a simple linear regression model (Eq. 2) was adjusted in order to formulate an equation that is able to estimate crop coefficient with NDVI values, referred to as $\mathrm{kc}_{\mathrm{NDVI}}$.

$$
\mathrm{y}=\mathrm{a}_{0}+\mathrm{b}_{\mathrm{i}} \mathrm{x}_{\mathrm{i}}
$$

where:

$\mathrm{y} \quad$ - dependent variable, $\mathrm{kc}_{\mathrm{NDVI}}$;

$\mathrm{x}_{\mathrm{i}} \quad$ - independent variable, average NDVI; and,

$a_{0}, b_{i}$ - adjusted coefficients of the linear model.

To validate the regression equation fitted for pivot 2 , this equation was applied to the average NDVI data of pivot 1 . The quality of the data obtained between estimated and observed values was assessed by correlation, determination coefficient $\left(\mathrm{R}^{2}\right)$, t-test at 0.05 significance level, and standard error of the estimate.

\section{Results AND Discussion}

NDVI results of the five pivots analysed are represented in Figure 2. In general, it can be observed that the variation in NDVI due to the phenological cycle of the crop, i.e., in response to the increase and decrease in sugarcane vegetative vigor. Maximum values of NDVI, close to 0.8 , were recorded from the date of $29 / 01 / 2017$, which means that the crop reached its highest vegetative growth. The increase in the vegetation index expresses the gain of biomass, while the reduction indicates that the crop begins its maturation process, in which there is

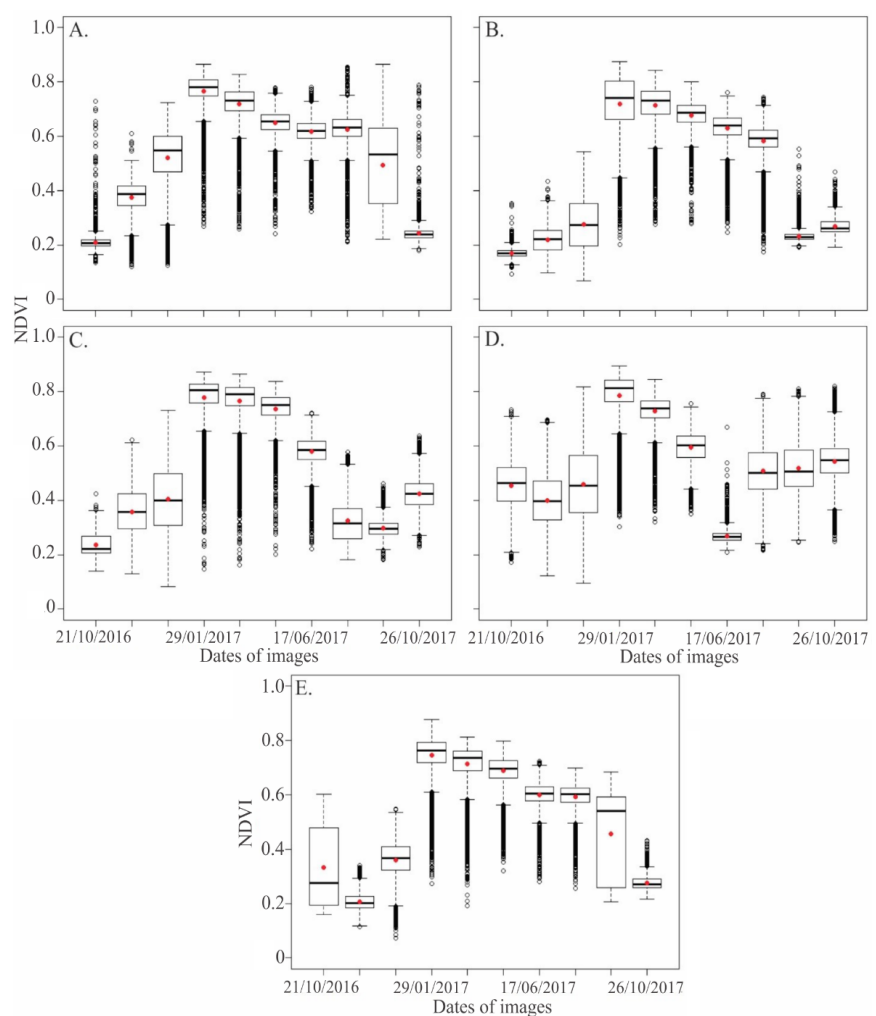

Figure 2. Normalized Difference Vegetation Index (NDVI) results of the five center pivots analysed: pivot 1 (A), pivot 2 (B), pivot 3 (C), pivot 4 (D) and pivot 5 (E) 
accumulation of saccharose. In this phase or at the beginning of crop phenological cycle, when the soil is exposed, the NDVI values were low, close to 0.2. According to Lima et al. (2013), under this condition, there is higher absorption of radiation in the near infrared band, which explains the low values of NDVI in the initial stages of the phenological cycle.

NDVI images of the analysed pivots are represented in Figure 3. Lower values are associated with the red color, corresponding to exposed soil, whereas higher values are associated with green, expressing good vegetative vigor of the crop.

It can be observed in pivot 1 (Figure 3A), on the first two dates analysed, the presence of exposed soil, and the spectral behavior of the soil is dominant in this period. Highest vegetative vigor was observed on the dates 29/01/2017 and $09 / 04 / 2017$, corresponding to the highest photosynthetic activity of the crop in the field. From 08/06/2017, vegetative vigor begins to decrease, represented by the sparse green color, which corresponds to the beginning of the crop maturation process, extending until $26 / 09 / 2017$. It can be noted that harvest began after $26 / 09 / 2017$, and that on the last date evaluated (26/10/2017) the soil became exposed again, closing the phenological cycle of the sugarcane crop.

Similar behavior was observed in the pivots 2 and 5 , Figures 3B and E, respectively. Lopes et al. (2011), studying the spatialization of soil moisture based on surface temperature and vegetation index, concluded that there is a direct relationship of sugarcane density and NDVI, a fact observed in the present study. It should be pointed out that for pivot 5 , on the first date, the crop was still being harvested in the field, with occurrence of exposed soil on the next date.

It is also important to highlight that, in general, sugarcane NDVI begins to decrease from the seventh month of the crop cycle on, indicating maximum value of leaf area and a slow growth in this phase, corroborating the data reported by Lucas \& Schuler (2007).

Formaggio \& Sanches (2017) report that a recently planted area has a similar spectral behavior to that of exposed soil, a fact observed in pivot 3 (Figure 3C) on the dates 11/10/2016 and $12 / 10 / 2016$, when there were surrounding rings with color of exposed soil. This fact is possibly associated with the existence of some problem related to water distribution by the sprinklers in this period; however, the same ring was not observed with the same intensity on the subsequent dates. Therefore, it can be stated that the problem was attenuated.

In pivot 4 (Figure 3D), the existence of the crop in the field can be observed already on the first date evaluated, despite the occurrence of some irregularities in the vegetation, and highest vegetative vigor was found on the dates 29/01/2017 and $09 / 04 / 2017$. On $17 / 08 / 2017$, this pivot had exposed soil and, subsequently, some vegetation in the field, representing the beginning of a new production cycle.

Ribeiro et al. (2017) report that digital processing of satellite images allows producers to identify abnormalities in the field and make corrective decisions along the season, hence obtaining better results. Thus, based on the NDVI image of pivot 4 (Figure 3D), it can be observed that, on the first three dates, green stripes that may represent some problem with sugarcane establishment in this period, also combined with the problem in irrigation management. On 08/06/2017, it is possible to note the beginning of the crop maturation process and the occurrence of rings again, with trend of exposed soil.

Figure 4 presents the adjusted equation based on the relationship between average NDVI and $\mathrm{kc}_{\mathrm{FAO}}$, considering the area of pivot 2. It can be observed that $71 \%$ of the variation in $\mathrm{kc}_{\mathrm{FAO}}$ value can be explained by the variation in the average $\mathrm{kc}_{\mathrm{NDVI}}$ of the sugarcane crop in the field. Based on the p-value obtained,

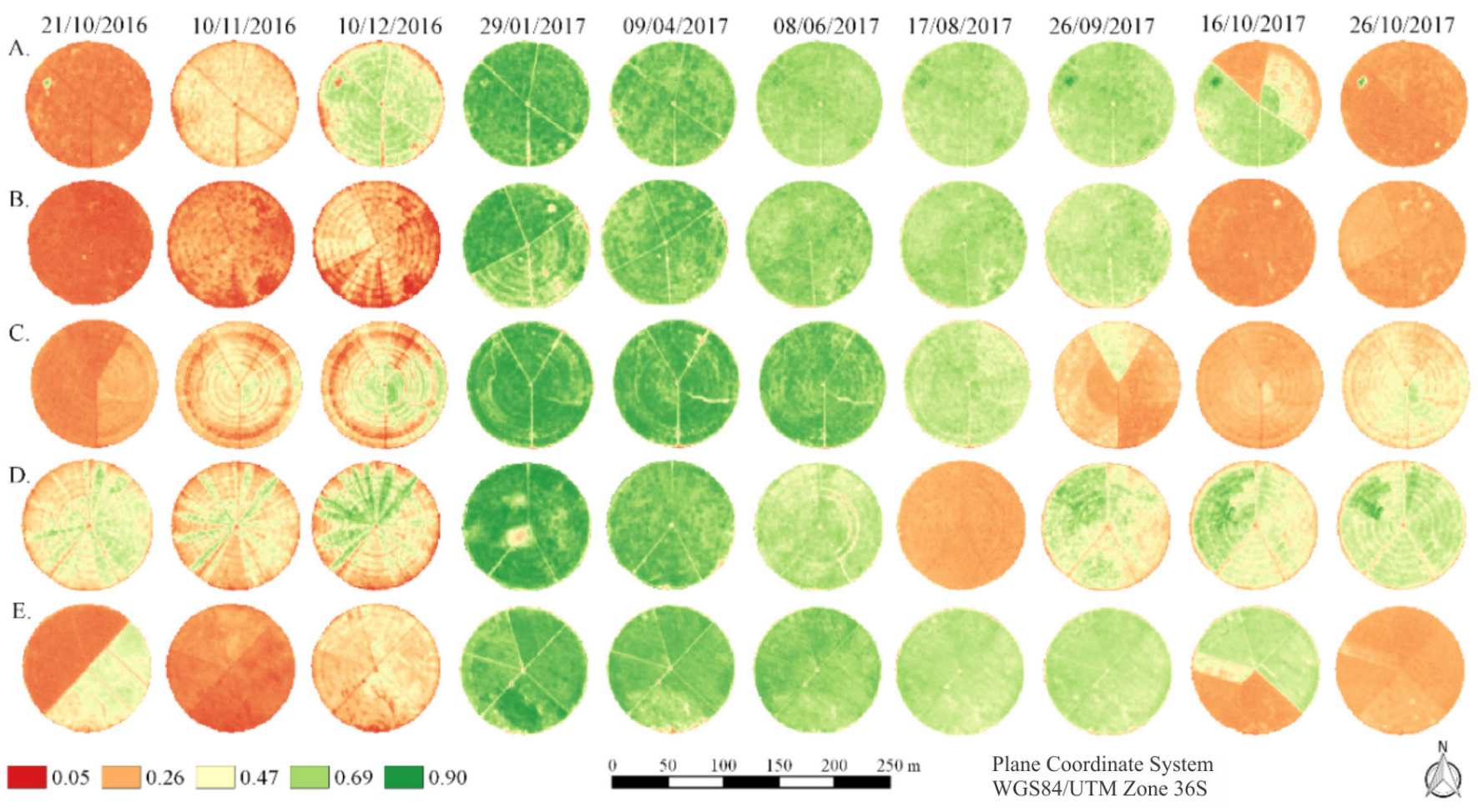

Figure 3. Temporal image of Normalized Difference Vegetation Index (NDVI) for the five center pivots analysed: pivot 1 (A), pivot $2(\mathrm{~B})$, pivot $3(\mathrm{C})$, pivot $4(\mathrm{D})$ and pivot $5(\mathrm{E})$ 


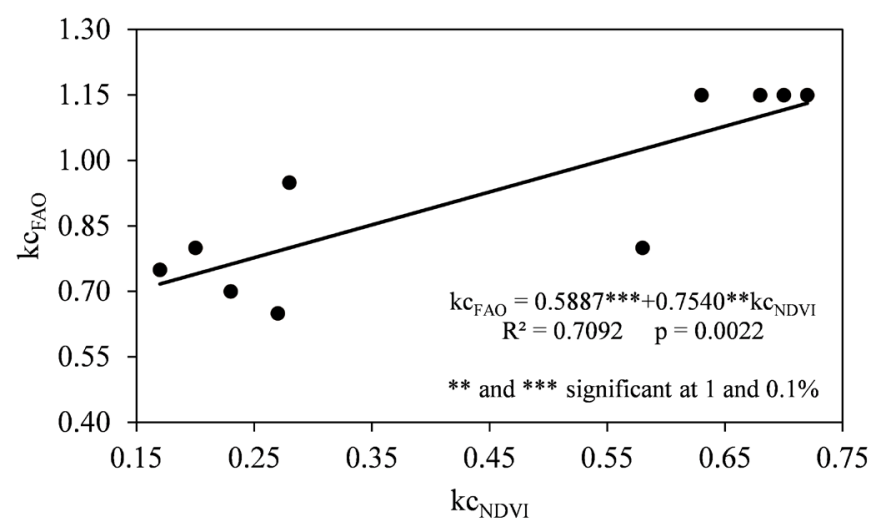

Figure 4. Linear regression adjust between the average value of $\mathrm{kc}_{\mathrm{FAO}}$ and $\mathrm{kc}_{\mathrm{NDVI}}$

it is possible to affirm that the adjustment was significant. This result was also found by Singh \& Irmak (2009), evidencing high correlation between $\mathrm{kc}_{\mathrm{NDVI}}$ and $\mathrm{kc}_{\mathrm{FAO}}$ values when establishing the relationship between $\mathrm{NDVI}_{\max }$ and $\mathrm{kc}_{\mathrm{FAO}}$ for corn and soybean crops in the Central South region of Nebraska state. It is important to point out that considering the average values of NDVI in this analysis led to obtaining better data adjustment, because there is a better representation of the crop in the field.

The average values of $\mathrm{kc}_{\mathrm{NDVI}}$ of pivot 1 were calculated using the adjustment equation shown in Figure 4. In the comparison between $\mathrm{kc}_{\mathrm{NDVI}}$ and $\mathrm{kc}_{\mathrm{FAO}}$ profiles (Figure 5), the curves showed a similar behavior. It can be noted that $\mathrm{kc}_{\mathrm{FAO}}$ had a slightly superior behavior compared to the other curves. Such behavior is due to the sensitivity of NDVI to crop vegetative vigor, besides considering the variability existing in the area, relating it to biotic and abiotic aspects. It is worth highlighting that $\mathrm{kc}_{\mathrm{FAO}}$, for not being related to the above-mentioned characteristics, will provide average estimates, whereas $\mathrm{kc}_{\mathrm{NDVI}}$ highlights areas with lower and higher water demands. However, the statistical analysis applied to these results showed, for pivot 2, determination coefficient of 0.73 , correlation of 0.86 , standard error of the estimate of 0.11 , and p-value of the regression of 0.0016 , hence considered as significant. In pivot 1 , the results were similar: $0.50,0.71,0.16$ and 0.02 , respectively.

Corroborating the results obtained in the present study, Esquerdo et al. (2011), analysing temporal profiles of NDVI generated from remote sensing data, with VGT-S10 product, for the soybean crop in Western Paraná, found similarity between $\mathrm{kc}_{\mathrm{NDVI}}$ and $\mathrm{kc}_{\mathrm{FAO}}$ curves.

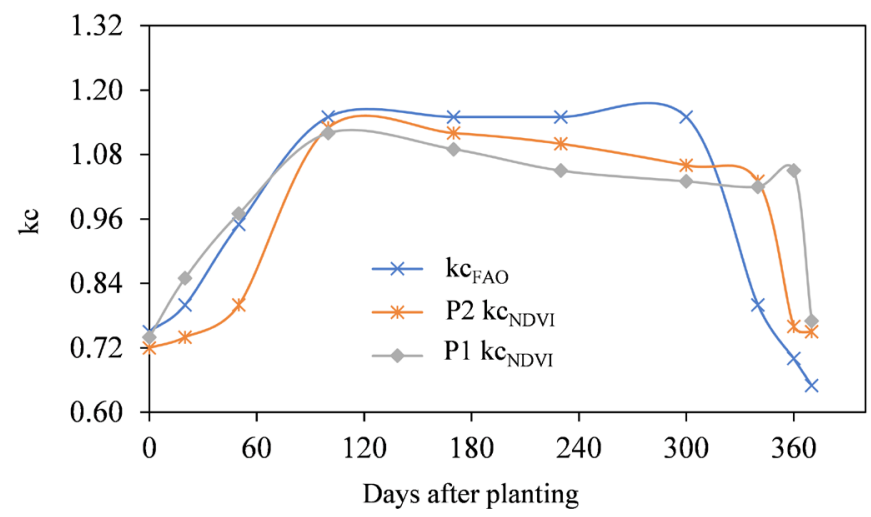

Figure 5. Temporal profiles of sugarcane crop coefficients $\mathrm{kc}_{\mathrm{FAO}}$ and $\mathrm{kc}_{\mathrm{NDVI}}$
Bezerra et al. (2010) claims that the spectral reflectance of agricultural crops was able to provide an indirect estimate of kc values, a fact that can be observed in the present study, through the curves of $\mathrm{kc}_{\mathrm{FAO}}$ and $\mathrm{kc}_{\mathrm{NDVI}}$, therefore highlighting that NDVI can be used as an indirect alternative to obtain the sugarcane crop coefficient, also in accordance with Oliveira et al. (2016).

\section{Conclusions}

1. Normalized Difference Vegetation Index (NDVI) calculation per center pivot proves to be effective in the monitoring of sugarcane crop in the field, and it is possible to perform both spatial and temporal analyses of the crop in the field.

2. NDVI can be used as an alternative to obtain the sugarcane crop coefficient.

\section{ACKNOWLedgments}

To the Coordenação de Aperfeiçoamento de Pessoal de Nível Superior (CAPES, Brazil) Finance code 001 and to the Fundação de Amparo à Pesquisa do Estado de Minas Gerais (FAPEMIG), for providing financial aid, and to Borlaug Higher Education for Agricultural Research and Development (BHEARD), for granting the Master's scholarship.

\section{Literature Cited}

Agrosmart. Imagens mensais de satélite NDVI-identifica anomalias nas lavouras. Available on: <https://www.agrosmart.com.br/ blog/imagens-de-satelite-agricultura-beneficios/>. Accessed on: Nov. 2017.

Alves, C. D.; Florenzano, T. G.; Alves, D. S.; Pereira, M. N. Mapping land use land cover changes in a region of sugarcane expansion using TM and MODIS data. Revista Brasileira de Cartografia, v.2, p.337-347, 2014.

Bernardi, A. C. de C.; Rabello, L. M.; Inamasu, R. Y.; Grego, C. R.; Andrade, R. G. Variabilidade espacial de parâmetros físicoquímica do solo e biofísicos de superfície em cultivo do sorgo. Revista Brasileira de Engenharia Agrícola e Ambiental, v.18, p.623630, 2014. https://doi.org/10.1590/S1415-43662014000600009

Bezerra, B. G.; Silva, B. B. da; Bezerra, J. R. C.; Brandão, Z. N. Evapotranspiração real obtida através da relação entre o coeficiente dual de cultura da FAO-56 e o NDVI. Revista Brasileira de Meteorologia, v.25, p.404-414, 2010. https://doi.org/10.1590/ S0102-77862010000300012

Cattani, C. E. V.; Garcia, M. R.; Mercante, E.; Johann, J. A.; Correa, M. M.; Oldoni, L. V. Spectral-temporal characterization of wheat cultivars through NDVI obtained by terrestrial sensors. Revista Brasileira de Engenharia Agrícola e Ambiental, v.21, p.769-773, 2017. https://doi.org/10.1590/1807-1929/agriambi. v21n11p769-773

Congedo, L. Semi-automatic classification plugin documentation: Release 5.0.1.1. Roma: Sapienza University of Rome, 2016. 201p.

Cordeiro, A. P. A.; Berlato, M. A.; Fontana, D. C.; Melo, R. W. de; Shimabukuro, Y. E.; Fior, C. S. Regiões homogêneas de vegetação utilizando a variabilidade do NDVI. Ciência Florestal, v.27, p.883896, 2017. https://doi.org/10.5902/1980509828638 
Esquerdo, J. C. D. M.; Zullo Junior, J.; Antunes, J. F. G. Use of NDVI/ AVHRR time-series profiles for soybean crop monitoring in Brazil. International Journal of Remote Sensing, v.32, p.3711-3727, 2011. https://doi.org/10.1080/01431161003764112

Formaggio, A. R.; Sanches, I. del A. Sensoriamento remoto em agricultura. São Paulo: Oficina de Textos, 2017. 288p.

Gao, F.; Anderson, M. C.; Zhang, X.; Yang, Z.; Alfieri, J. G.; Kustas, W. P.; Mueller, R.; Johnson, D. M.; Prueger, J. H. Toward mapping crop progress at field scales through fusion of Landsat and MODIS imagery. Remote Sensing of Environment, v.188, p.9-25, 2017. https://doi.org/10.1016/j.rse.2016.11.004

Kamble, B.; Irmak, A.; Hubbard, K. Estimating crop coefficients using remote sensing-based vegetation index. Remote Sensing, v.5, p.1588-1602, 2013. https://doi.org/10.3390/rs5041588

Li, Z.; Liu, X.; Ma, T.; Kejia, D.; Zhou, Q.; Yao, B.; Niu, T. Retrieval of the surface evapotranspiration patterns in the alpine grasslandwetland ecosystem applying SEBAL model in the source region of the Yellow River, China. Ecological Modelling, v.270, p.64-75, 2013. https://doi.org/10.1016/j.ecolmodel.2013.09.004

Lima, G. C.; Silva, M. L. N.; Curi, N.; Silva, M. A. da; Oliveira, A. H.; Avanzi, J. C.; Ummus, M. E. Avaliação da cobertura vegetal pelo índice de vegetação por diferença normalizada (IVDN). Revista Ambiente e Água, v.8, p.204-214, 2013.

Lopes, H. L.; Accioly, L. J. de O.; Silva, F. H. B. B. da; Sobral, M. do C. M.; Araújo Filho, J. C. de; Candeias, A. L. B. Espacialização da umidade do solo por meio da temperatura da superfície e índice de vegetação. Revista Brasileira de Engenharia Agrícola e Ambiental, v.15, p.973-980, 2011. https://doi.org/10.1590/S141543662011000900014

Lucas, A. de A.; Schuler, C. A. B. Análise do NDVI/NOAA em canade-açúcar e Mata Atlântica no litoral norte de Pernambuco, Brasil. Revista Brasileira de Engenharia Agrícola e Ambiental, v.11, p.607614, 2007. https://doi.org/10.1590/S1415-43662007000600009

MAE - Ministério de Administração Estatal. Perfil do distrito de Nhamatanda. Maputo: MAE, 2005. 55p.
Moreira, M. A. Fundamentos do sensoriamento remoto e metodologias de aplicação. 4.ed. Viçosa: Editora UFV, 2011. 422p.

Oliveira, T. C. de; Ferreira, E.; Dantas, A. A. A. Temporal variation of normalized difference vegetation index (NDVI) and calculation of the crop coefficient $\left(\mathrm{K}_{\mathrm{c}}\right)$ from NDVI in areas cultivated with irrigated soybean. Ciência Rural, v.46, p.1683-1688, 2016. https:// doi.org/10.1590/0103-8478cr20150318

Ponzoni, F. J.; Shimabukuro, Y. E.; Kuplich, T. M. Sensoriamento remoto da vegetação. 2.ed. São Paulo: Oficina de Textos, 2012. $160 \mathrm{p}$.

QGIS Development Team. Geographic Information System (QGIS) software, version 2.16. Chigago: Open Source Geospatial Foundation, 2016. sp.

Ribeiro, R. B.; Filgueiras, R.; Ramos, M. C. A.; Almeida, L. T. de; Generoso, T. N.; Monteiro, L. I. B. Variabilidade espaço-temporal da condição da vegetação na agricultura irrigada por meio de imagens sentinel. Revista Brasileira de Agricultura Irrigada, v.11, p.1884-1893, 2017. https://doi.org/10.7127/rbai.v11n600648

Risso, J.; Rizzi, R.; Rudoff, B. F. T.; Adami, M.; Shimabukuro, Y. E.; Formaggio, A. R.; Epiphanio, R. D. V. Índices de vegetação MODIS aplicados na discriminação de áreas de soja. Pesquisa Agropecuária Brasileira, v.47, p.1317-1326, 2012. https://doi. org/10.1590/S0100-204X2012000900017

Rodrigues, M. T.; Rodrigues, B. T. Aplicação do índice da vegetação por diferença normalizada (NDVI) em imagens CBERS 2B no município de Botucatu-SP. Revista Brasileira de Engenharia de Biossistemas, v.6, p.139-147, 2012. https://doi.org/10.18011/ bioeng2012v6n3p139-147

Shimabukuro, Y. E.; Novo, E. M.; Ponzoni, F. J. Índice de vegetação e modelo linear de mistura espectral no monitoramento da região do pantanal. Pesquisa Agropecuária Brasileira, v.33, p.1729-1737, 1998.

Singh, R.; Irmak, A. Estimation of crop coefficients using satellite remote sensing. Journal of Irrigation and Drainage Engineering, v.135, p.597-608, 2009. https://doi.org/10.1061/(ASCE)IR.19434774.0000052 